\title{
USE OF ANTICOAGULANTS IN CEREBRAL VASCULAR PATHOLOGY
}

\author{
CRISTINA FLORENTINA PLEȘA ${ }^{1}$, CAMELIA NICOLAE ${ }^{2 *}$, CARMEN ADELLA SÎRBU ${ }^{1}$, \\ ROXANA NEMEȘ ${ }^{1}$, ALINA PĂUNESCU ${ }^{3}$, MONICA MARILENA ȚÂNȚU ${ }^{3}$ \\ ${ }^{I}$ Central Universitary Emergency Military Hospital “Carol Davila”, Department of neurology, Calea Plevnei Street 134, \\ Bucharest, Romania \\ 2" Carol Davila" University of Medicine and Pharmacy, Dionisie Lupu 37, Bucharest, Romania \\ ${ }^{3}$ University of Piteşti, Faculty of Sciences, Department of Medical Care Assistance and Kinesiotherapy, Târgu din Vale 1, \\ Piteşti, Romania
}

*corresponding author:dr_camelia_nicolae@yahoo.com

Manuscript received: December 2018

\begin{abstract}
The aetiology of ischemic vascular stroke (IVS) is various, the most common cause being cardioembolic, and anticoagulation treatment plays an essential role in the prevention of cerebral ischemic events. Atrial fibrillation (AF) is the pathological condition requiring long-term anticoagulant therapy for preventive purposes, both primary and secondary. Complications, disabilities and mortality are more common in patients who had an ischemic stroke associated with atrial fibrillation than in those without AF. The indication, type and dose of anticoagulant depend on the stage and size of the ischemic lesion, thromboembolic and haemorrhagic risk and patient compliance. According to the 2018 European Heart Rhythm Association Practical Guide on the use of non-vitamin K antagonist oral anticoagulants in patients with atrial fibrillation, among the different types of anticoagulants indicated in the case of AF and IS, it would be preferable to use new anticoagulants. Anticoagulation medication is indicated in the acute stage only in patients with a clear thromboembolic source. Anticoagulant treatment has a well-established role over time as a result of numerous clinical trials, its use having a guide recommendation, but the particularity of each case as well as personal experience strengthens the indication.
\end{abstract}

\section{Rezumat}

Etiologia accidentului vascular cerebral ischemic (IVS) este diferită, cea mai comună cauză fiind cardioembolică, iar tratamentul anticoagulant joacă un rol esențial în prevenirea accidentelor cerebrale ischemice. Fibrilația atrială (AF) este starea patologică care necesită terapie anticoagulantă pe termen lung în scopuri preventive, atât primare, cât şi secundare. Complicațiile, dizabilitățile și mortalitatea sunt mai frecvente la pacienții care au avut un accident vascular cerebral ischemic asociat cu fibrilația atrială comparativ cu pacientii fără această patologie. Indicația, tipul și doza de anticoagulant depind de stadiul și mărimea leziunii ischemice, de riscul tromboembolic și hemoragic și de complianța pacientului. În conformitate cu ghidurile în vigoare privind utilizarea anticoagulantelor orale antagoniste non-vitamine K la pacienții cu fibrilație atrială, printre diferitele tipuri de anticoagulante indicate în cazul AF și IS, ar fi preferabil să se utilizeze anticoagulante noi. Medicamentul anticoagulant este indicat în stadiul acut numai la pacienții cu o sursă tromboembolică clară. Tratamentul anticoagulant are un rol bine stabilit de-a lungul timpului ca rezultat al numeroaselor studii clinice, utilizarea acestuia având o recomandare orientativă, dar particularitatea fiecărui caz, precum și experiența personală consolidează indicația.

Keywords: stroke, anticoagulants, haemorrhagic risk

\section{Introduction}

Vascular stroke (VS) is an important pathology which generates disability and it is also the second leading cause of worldwide mortality [54]. Six months after VS, $50 \%$ of patients have motor deficiency, $35 \%$ depression, $30 \%$ require movement help, $19 \%$ have speaking disorders, $26 \%$ remain dependent in daily activities, and many are institutionalized [29]. Studies conducted worldwide for a period of 20 years (1990-2010) showed an increase in the incidence of both VS (37\%) and HVS (haemorrhagic vascular stroke, $47 \%$ ), as well as an increase in the rate of stroke deaths by about 20\% [18]. Approximately 600,000 new cases of stroke are recorded annually in Europe [37]. In a EUROSTAT report (2016) there is an $18.7 \%$ stroke incidence in Romania (2013), this ranking our country second in Europe, after Bulgaria [34].

Treatment of stroke and recovery of post-VS involve significant costs for the patient, which have a significant impact on the quality of life, as well as on health systems, requiring multiple material, financial and human resources. A cost estimation in 27 EU countries estimates an annual level of 27 billion euros, of which $48.6 \%$ for medication, investigation, specialist, nursing, $22.3 \%$ for indirect costs, and the remaining of $29.1 \%$ representing informal expenses [3]. 
FARMACIA, 2019, Vol. 67, 1

\section{The role of anticoagulants in vascular pathology}

Considering these aspects, of particular importance is the primary prevention of VS, by combating both risk factors as well as the secondary prevention, in cases with already established vascular neurological events. Anticoagulant treatment finds its utility in both forms of prevention, consistent with the aetiology of the stroke, the stage of the disease (acute or chronic), associated pathology and evolution under the initiated treatment.

The therapeutic measures in the case of constituted TIA (Transient Ischemic Accident)/IVS are complex. They aim at the pathophysiology, prevention of complications, recurrences, pursuing a quicker and less disability-related neurorehabilitation.

For patients who have undergone acute IVS, the risk of recurrence is estimated at $11.1 \%$ per year, at $24.4 \%$ at 5 years, increasing significantly at 10 years $(39.5 \%)$ [27, 39]. This data may be larger in reality because not all TIAs or even VSs benefit from diagnosis because many are silent or with non-specific VS symptoms, the patient not presenting himself to the doctor. Thus, anticoagulants, by influencing some factors involved in the coagulation cascade, intervene in lowering the risk of recurrence of vascular embolisms with different localizations, including the cerebral level, being a major pharmacological class in antithrombotic therapy. Furthermore, in the case of installed thrombosis, they reduce the risk of aggravation by acting directly on the thrombus, thus limiting its extension.

Anticoagulants prove their usefulness, along with other specific care measures, in the prevention of thromboembolic phenomena caused by the condition of the neurological patient (prolonged bed immobilization, muscle tone decrease).

Studies have shown an efficacy of anticoagulant therapy in the prevention of symptomatic pulmonary thromboembolism and deep vein thrombosis, but without a significant effect on the mortality rate or degree of disability in patients previously treated for stroke. Also, no statistical differences were found between the types of anticoagulant, but an important element remains the risk/benefit ratio for each. Thus, the anticoagulant choice should take into account the risk of haemorrhage, which can not be definitely established, but can be assessed by bleeding scores and the therapeutic decision is based mainly on clinical the experience $[14,57]$.

\section{Influence of anticoagulants on the pathophysiological mechanisms of ischemic stroke}

The aetiology of ischemic stroke is various. Knowing the pathophysiological mechanisms of cerebral ischemia and coagulation is essential. These are the basis of the therapeutic indication according to the guidelines and justify the emergency measures necessary for the observation of the concept of the therapeutic window. IVS has thrombotic causes $(45 \%)$, embolic causes $(20 \%)$, but in a significant percentage of cases the aetiology is unknown (cryptogenic) [28].

Thrombosis is initiated in the vascular wall as a result of endothelial dysfunction, especially due to the presence of many vascular risk factors (AHT arterial hypertension, endothelial dysfunction, carotid atheromatosis). There are rare situations where radiotherapy or local trauma triggers the thrombogenic process.

Cardiac embolism (auricular intracytopathic thrombosis or left ventricular hypokinesia, atrial fibrillation (AF), patent foramen ovale) or arterial (carotid or aortic) atheromatosis is frequently incriminated in IVS occurrence.

Surgical interventions may predispose patients to IVSs by increasing the risk of developing intra or post-procedural emboli (blood, fat or airborne). There are other rare causes, especially in the youngs, but with a major impact on the evolution, prognosis and quality of life of the patient, such as arterial (carotid or vertebral) dissections, clotting disorders [41], infectious or toxic (through drug abuse) [7].

A distinct cerebral vascular pathology is represented by venous sinus thrombosis, the leading cause of cerebral venous infarction, with a clear indication of anticoagulant therapy, initiated from the onset phase. If a thrombophilic or prothrombotic status is associated, chronic anticoagulation is required.

Atrial fibrillation is the pathological condition requiring long-term anticoagulant therapy for preventive purposes, both primary and secondary. The type and dose of anticoagulant is recommended taking into account the associated pathology and the risk of bleeding. Classical anti-vitamin $\mathrm{K}$ therapy has its proven beneficial role over time, but with some limitations such as slow-setting effect, narrow therapeutic window, the need for routine monitoring of coagulation, the influence on the therapeutic concentration of certain foods or drugs, frequent dose adjustments, sometimes unpredictable and with bleeding risks. All these limitations sometimes lead to therapeutic inefficiency.

Patients with AF and IVS experience a high rate of complications and recurrences, often with severe disability and a significant mortality.

A 2005 study demonstrated that recurrence of ischemic vascular events after one year and the incidence of death were more common in patients with $\mathrm{AF}(6.9 \%$ versus $4.7 \%$ respectively $49.5 \%$ 
versus $27.1 \%$ ) [9]. Other studies compared the risk of stroke and death in AF patients, whether or not with anti-vitamin $\mathrm{K}$ treatment. The results indicated a $64 \%$ decrease of stroke risk and $26 \%$ decrease of death due to anticoagulant therapy $[19,35]$.

In 2009, the RE-LY study (The Randomized Evaluation of Long-Term Anticoagulation Therapy) demonstrated the superiority of nonvitamin $\mathrm{K}$ antagonist oral anticoagulants (NOAC) treatment (dabigatran) - at high dose (150 mg x 2 per day) compared to anti-vitamin $\mathrm{K}$ therapy, in terms of reducing the risk of IVS with $35 \%$, mortality with $15 \%$, intra-cerebral haemorrhage with $59 \%$, but with $48 \%$ more frequent digestive bleeding. The results were similar for major haemorrhage [12, 13]. Researches on $110 \mathrm{mg}$ oncea-day dosing therapy with dabigatran have showed similar effects in reducing stroke risk, mortality and gastrointestinal haemorrhage, but a risk of $70 \%$ intracranial haemorrhage and $20 \%$ major haemorrhage. The favourable RE-LY profile was also confirmed by an FDA study (U.S. Food and Drug Administration) conducted in 134,000 reallife patients [23].

A meta-analysis of four clinical trials (RELY [49], ENGAGE AF-TIMI 48 (The Effective Anticoagulation with Factor $\mathrm{Xa}$ Next Generation in Atrial Fibrillation - Thrombolysis in Myocardial Infarction 48) [22], ROCKET AF[44], ARISTOTLE [24] ), which compared the effect of NOACs (dabigatran, edoxaban, rivaroxaban, apixaban) with anti-vitamins $\mathrm{K}$ in preventing IVS in patients with AIF, revealed a low risk of recurrence of cerebral ischemia in NOAC treatment. The extension of the RELY study, the RELY-ABLE study (The Long-Term Multicenter Observational Study of Dabigatran Treatment in Patients with Atrial Fibrillation), showed the maintenance of the systemic or cerebral embolism prevention effect without increasing the risk of major bleeding or death, irrespective of the cause, for a longer period than 6 years [17]. These side effects of NOAC versus anti-vitamin $\mathrm{K}$ were also followed in other studies, such as the Danish study of 2016 showing superior safety for dabigatran and apixaban compared to rivaroxaban or anti-vitamin $\mathrm{K}$. With regard to low doses of NOAC, data showed that dabigatran is preferable to apixaban or rivaroxaban, given that, under similar conditions of recurrence and mortality risk, it has caused a significantly lower number of haemorrhages. Apixaban and dabigatran had a significantly lower risk of death or major bleeding accidents compared with wafarin [52]. The existence of idarucizumab, the specific neutralizing agent, increases the safety of dabigatran treatment, which makes it even more recommended for emergency surgery, bleeding, but also for recurrence of IVS with thrombolysis indication.

There have been studies comparing the prophylactic effect of anticoagulants with that of the antiaggregants. In 2012, the AVERROES (Apixaban Versus Acetylsalicylic Acid (ASA) study to Prevent Stroke in Atrial Fibrillation Patients Who Have Failed or Are Unsuitable for Vitamin K Antagonist Treatment) highlighted the importance of anticoagulant treatment in the AIF, demonstrating a superior efficacy to anti-platelet therapy, both in primary and secondary prevention of IVS/TIA, in patients who presented AF [16]. Antiaggregants are used in the presence of AF only in the acute phase of IVS, for a variable period, determined by the IVS aspect and the risk of bleeding. Thus, the 2016 European Society of Cardiology (ESC) Guidelines for the management of atrial fibrillation developed in collaboration with European Association for Cardio-Thoracic Surgery (EACTS) [59] point out that in an acute AF and IVS patients no immediate anticoagulant medication (Class III A) should be administered. In most patients, it is recommended to initiate anticoagulant therapy after $4-14$ days since the clinical onset, with high results after 90 days of treatment on systemic embolism or haemorrhage [42]. The elevated blood pressure of stroke (assessed by the functional score NIHSS - The National Institutes of Health Stroke Scale score), the high haemorrhage risk (assessed by CHADS-VASC score) and the anticoagulant type are factors that may affect the favourable outcomes of the anticoagulant therapy. Mild or moderate stroke with a NIHSS $<9$ has a low risk of haemorrhagic transformation, as demonstrated by a rivaroxaban study in 2016 [21]. Also, in the case of AF patients who receive anticoagulant medication and develop a moderate/severe IVS, it is necessary to discontinue anticoagulation for a period of 3 - 12 days. It will be resumed according to the size/appearance of the acute stroke and the risk of bleeding (class II indication, evidence C) [25].

In the event of a haemorrhagic transformation of IVS, initiation or maintenance of antiaggregant or anticoagulant therapy is dictated by the specificity of each case, taking into account the indications, associated pathology, bleeding risk, stroke severity, with Class II guidance recommendations, B level evidence [32]. The presence of a cerebral haemorrhage in anticoagulated patients with $\mathrm{AF}$ requires interruption for $4-8$ weeks, assessing the risk of bleeding, identifying and combating the factors predisposing to haemorrhage. Combination therapy following stroke or TIA is not recommended for patients associating coronary artery disease and atrial fibrillation because it has not shown a decrease in the risk of new vascular cerebral events (Class III indication, evidence B), 
FARMACIA, 2019, Vol. 67, 1

except for coronary stent implant or unstable angina.

Of the different types of anticoagulants indicated in the case of AF and IVS, it would be preferable to use NOACs, both in terms of efficacy, but also of safety and compliance with the treatment.

\section{The therapeutic indication of anticoagulants depending on the stage of stroke}

The efficacy of anticoagulants has been clinically proven and sustained over time by numerous multicentred studies and their results have grounded evidence-based medicine and have received guidance in medical practice. There have been controversies as to when to initiate anticoagulant therapy after an ischemic stroke. Anticoagulant treatment in the acute phase of IVS can be only discussed after a throughout assessment of the risk of bleeding depending on the appearance of the cerebral vessels and the size of the stroke, and of course after exclusion of brain bleeding or other conditions with haemorrhagic risk (AHT, etc.). The magnitude of an infarction can be clinically appreciated by performing the NIHSS score, but imaging is more advantageous, preferably by angioCT (angio computer tomography) - CT scan (ASPECT score - Alberta Stroke Program Early CT Score) because it is possible to identify asymptomatic areas, most often in the association cortex.

The utility of anticoagulants in the acute stage has been demonstrated in the case of TIA in patients with evident thromboembolic source, such as AF, auricular thrombosis, thrombophilic status, otherwise not being superior to anti-aggregation therapy. There are divided opinions about the type of anticoagulant, the dose, the mode of administration and duration of treatment [1].

Unfractionated heparin and low molecular weight heparins (LMWHs) were evaluated for their role in acute IVS in terms of preventing progress, reducing disability and preventing recurrences, but the results of the studies did not clear these issues. Thus, in a Norwegian study, patients with embolic stroke treated in emergency with dalteparin had an $8 \%$ rate of early recurrence (the first 7 days) [6], while another study revealed a risk of early recurrent embolism of $12 \%[10,11]$ in the same type of stroke without anticoagulant treatment.

The effect of unfractionated heparin was evaluated as compared to the saline solution administered intravenously within the first 3 hours since the onset and continued for 5 days [31] in the case of superfluous IVS. The monocentric study was conducted on 418 patients with non-lacunar hemispheric strokes (with cardioembolic, atherothrombotic or unknown/ undetermined), and observed that the favourable outcome after 90 days was in favour of the heparin-treated group (38.9\% vs. $28,6 \%, \mathrm{p}=0.025)$, with a higher risk of intramuscular or extracranial haemorrhage, but without a higher incidence of mortality. Other inconclusive results were the consequence of not taking into account the aetiology of stroke when heparin was administered immediatetly [15].

Following numerous clinical trials, the new Stroke Management Guide (2018) does not recommend emergency anticoagulation therapy with the goal of immediate prevention of recurrence or improvement of clinical outcome or general outcomes [57, 60]. Regarding the utility of NOACs or factor Xa inhibitors in acute thrombotic IVS, a well-established indication [4] has not been demonstrated [4], and there is insufficient data to do so (Class II recommendation, B level evidence). The ARTSS study (Argatroban with Recombinant Plasminogen Activator for Acute Stroke) in 2012 demonstrated the efficacy of the association between the tissue plasminogen activator and argatroban in partial or complete thrombosis patients proven by transcranial Doppler and did not show an increased risk of bleeding in the case of association compared to mono-therapy [5].

TOAST study (The Trial of Org 10172 in Acute Stroke Treatment) with danaparoid administered in the first 7 days since the onset [51] versus placebo, revealed a better evolution under anticoagulation for patients with severe or occlusive atherosclerosis ( $68 \%$ versus $55 \%$ with placebo), but did not notice a significant difference compared to placebo in terms of overall outcomes at 3 months (75\% versus $74 \%$ ). The Doppler exam has the role in identifying patients who may be recommended for this treatment.

In the case of IVS due to large vessel occlusion, the comparative evolution of nadroparin anticoagulant treatment ( $0.4 \mathrm{~mL}$ x 2 per day subcutaneously) $v s$. anti-aggregation (aspirin $160 \mathrm{mg} /$ day) initiated in the first 48 hours for 10 days, in the FISS study, did not reveal statistically significant differences after 6 months (73\% versus $69 \%$ ) [58]. In this regard, the Guidelines for Early Management of Patients with Acute Ischemic Stroke mention that urgent or shortterm anticoagulation in the case of symptomatic stenosis of the internal carotid artery or nonocclusive extracranial thrombosis is not sustained, intravenous heparin having the same utility as well as LMWHs, with class II indication, B level evidence $[40,55]$. To reduce the risk of recurrence or other cardiovascular events in the case of noncardioembolic stroke, the platelet antiaggregant has Class I indication and its substitution with warfarin is not beneficial (Class III recommendation).

In case of arterial dissection (vertebral or carotid in extracranial segment), both anti-aggregation and anticoagulant treatment can be administered between 
FARMACIA, 2019, Vol. 67, 1

3 and 6 months (class II recommendation, B evidence), without statistically significant differences after 3 months regarding the risk of major bleeding and mortality, regardless the cause of ischemic stroke or dissection side [8,33]. Anticoagulation treatment is taken into account in the presence of coagulation disorders in patients with ischemic stroke (Class II indication, B level).

\section{Conclusions}

Anticoagulants are an elective medication in the primary and secondary prevention of ischemic stroke by cardioembolic mechanism. The type and dose of anticoagulant are dictated by the characteristics of each case. The timing of initiation of the anticoagulant is established in most patients with IVS and AF according to the 2016 ESC Guidelines for the management of atrial fibrillation (developed in collaboration with EACTS). Anticoagulant treatment has its well-established role over time as a result of numerous clinical trials, its use having a guide recommendation, but the specificity of each case, as well as personal experience strengthens the indication.

\section{References}

1. Adams HP Jr, Emergent use of anticoagulation for treatment of patients with ischemic stroke. Stroke, 2002; 33: 856-861.

2. Ageno W, Gallus AS, Wittkowsky A, Crowther M, Hylek EM, Palareti G, Oral anticoagulant therapy: Antithrombotic therapy and prevention of thrombosis, $9^{\text {th }}$ ed: American College of Chest Physicians Evidence-Based Clinical Practice Guidelines. Chest, 2012; 141(2 Suppl):e44S-e88S

3. di Carlo A, Human and economic burden of stroke. Age and Ageing, 2009; 38(1): 4-5.

4. Barreto $\mathrm{AD}$, Alexandrov $\mathrm{AV}$, Lyden $\mathrm{P}$, Lee $\mathrm{J}$, Martin-Schild S, Shen L, Wu TC, Sisson A, Pandurengan R, Chen Z, Rahbar MH, Balucani C, Barlinn K, Sugg RM, Garami Z, Tsivgoulis G, Gonzales NR, Savitz SI, Mikulik R, Demchuk AM, Grotta JC, The Argatroban and Tissue-Type Plasminogen Activator Stroke Study: final results of a pilot safety study. Stroke, 2012; 43: 770-775.

5. Barreto AD, Ford GA, Shen L, Pedroza C, Tyson J, Cai C, Rahbar MH, Grotta JC, ARTSS-2 Investigators, Randomized, multicenter trial of ARTSS-2 (Argatroban With Recombinant Tissue Plasminogen Activator for Acute Stroke). Stroke, 2017; 48(6): 1608-1616.

6. Berge E, Abdelnoor M, Nakstad PH, Sandset PM, Low molecular-weight heparin versus aspirin in patients with acute ischaemic stroke and atrial fibrillation: A double-blind randomised study. HAEST Study Group. Heparin in Acute Embolic Stroke Trial. Lancet, 2000; 355: 1205-1210.

7. Blank-Reid C, How to have a stroke at an early age: The effects of crack, cocaine and other illicit drugs. $J$ Neurosci Nurs., 1996; 28:19-27
8. CADISS Trial Investigators, Markus HS, Hayter E, Levi C, Feldman A, Venables G, Norris J, Antiplatelet treatment compared with anticoagulation treatment for cervical artery dissection (CADISS): a randomised trial. Lancet Neurol., 2015; 14: 361-367.

9. Marini C, De Santis F, Sacco S, Russo T, Olivieri L, Totaro R, Carolei A, Contribution of atrial fibrillation to incidence and outcome of ischemic stroke. Stroke, 2005; 36: 1115-1119.

10. [No authors listed], Cerebral embolism study group. Cardioembolic stroke, early anticoagulation, and brain hemorrhage. Arch Intern Med., 1987; 147: 636640.

11. [No authors listed], Cerebral embolism study group. Immediate anticoagulation of embolic stroke: Brain hemorrhage and management options. Stroke, 1984; 15: 779-789.

12. Connolly SJ, Wallentin L, Yusuf S, Additional Events in the RE-LY Trial. $N$ Engl J Med., 2014; 371: 1464-1465.

13. Connolly SJ, Ezekowitz MD, Yusuf S, Reilly PA, Wallentin L, Newly identified events in the RE-LY trial. N Engl J Med., 2010; 363(19): 1875-1876.

14. Dennis M, Caso V, Kappelle LJ, Pavlovic A, Sandercock P, European Stroke Organisation (ESO) guidelines for prophylaxis for venous thromboembolism in immobile patients with acute ischaemic stroke. Eur Stroke J., 2016; 1: 6-19.

15. Diener HC, Ringelstein EB, von Kummer R, Langohr HD, Bewermeyer $\mathrm{H}$, Landgraf $\mathrm{H}$, Treatment of acute ischemic stroke with the lowmolecular-weight heparin certoparin: Results of the TOPAS trial. Therapy of Patients With Acute Stroke (TOPAS) Investigators. Stroke, 2001; 32: 22-29.

16. Diener HC, Eikelboom J, Connolly SJ, Joyner CD, Hart RG, Lip GY, O'Donnell M, Hohnloser SH, Hankey GJ, Shestakovska O, Yusuf S, Apixaban versus aspirin in patients with atrial fibrillation and previous stroke or transient ischaemic attack: a predefined subgroup analysis from AVERROES, a randomised trial. Lancet Neurol., 2012; 11(3): 225231

17. Ezekowitz MD, Eikelboom J, Oldgren J, Reilly PA, Brueckmann M, Kent AP, Pogue J, Spahr J, Clemens A, Noack H, Diener HC, Wallentin L, Yusuf S, Connolly SJ, Long-term evaluation of dabigatran 150 vs. $110 \mathrm{mg}$ twice a day in patients with nonvalvular atrial fibrillation. Europace, 2016; 18(7): 973-978.

18. Feigin VL, Forouzanfar MH, Krishnamurthi R, Mensah GA, Connor M, Bennett DA, Moran AE, Sacco RL, Anderson L, Truelsen T, O'Donnell M, Venketasubramanian N, Barker-Collo S, Lawes CM, Wang W, Shinohara Y, Witt E, Ezzati M, Naghavi M, Murray C, Global Burden of Diseases, Injuries, and Risk Factors Study 2010 (GBD 2010), GBD Stroke Experts Group.Global and regional burden of stroke during 1990-2010: findings from the Global Burden of Disease Study 2010. Lancet. 2014; 383(9913): 245-254.

19. Fuster V, Rydén LE, Cannom DS, Crijns HJ, Curtis $\mathrm{AB}$, Ellenbogen KA, Halperin JL, Le Heuzey J-Y, Kay GN, Lowe JE, Olsson SB, Prystowsky EN, Tamargo JL, Wann S, Smith SC, Jacobs AK, Adams 
FARMACIA, 2019, Vol. 67, 1

CD, Anderson JL, Antman EM, Hunt SA, Nishimura R, Ornato JP, Page RL, Riegel B, Priori SG, Blanc JJ, Budaj A, Camm AJ, Dean V, Deckers JW, Despres C, Dickstein K, Lekakis J, McGregor K, Metra M, Morais J, Osterspey A, Zamorano JL, ACC/AHA/ESC 2006 guidelines for the management of patients with atrial fibrillation executive summary: a report of the American College of Cardiology/American Heart Association Task Force and the European Society of Cardiology Committee for Practice Guidelines (Writing Committee to Revise the 2001 Guidelines for the Management of Patients With Atrial Fibrillation). $J$ Am CollCardiol., 2006; 48: 854-906

20. Garcia DA, Baglin TP, Weitz JI, Samama MM, Parenteral anticoagulants: antithrombotic therapy and prevention of thrombosis, $9^{\text {th }}$ ed: American College of Chest Physicians Evidence Based Clinical Practice Guidelines. Chest, 2012; 141: 24S-43S.

21. Gioia LC, Kate M, Sivakumar L, Hussain D, Kalashyan H, Buck B, Bussiere M, Jeerakathil T, Shuaib A, Emery D, Butcher K, Early rivaroxaban use after cardioembolic stroke may not result in hemorrhagic transformation: a prospective magnetic resonance imaging study. Stroke, 2016; 47: $1917-$ 1919.

22. Giugliano RP, Ruff CT, Braunwald E, Murphy SA, Wiviott SD, Halperin JL, Waldo AL, Ezekowitz MD, Weitz JI, Špinar J, Ruzyllo W, Ruda M, Koretsune Y, Betcher J, Shi M, Grip LT, Patel SP, Patel I, Hanyok JJ, Mercuri M, Antman EM, Edoxaban versus warfarin in patients with atrial fibrillation. $N$ Engl J Med., 2013; 369(22): 20932104

23. Graham DJ, Reichman ME, Wernecke M, Zhang R, Southworth MR, Levenson M, Sheu TC, Mott K, Goulding MR, Houstoun M, MaCurdy TE, Worrall C, Kelman JA, Cardiovascular, bleeding, and mortality risks in elderly Medicare patients treated with dabigatran or warfarin for nonvalvular atrial fibrillation. Circulation, 2015; 131(2): 157-164.

24. Granger CB, Alexander JH, McMurray JJ, Lopes RD, Hylek EM, Hanna M, Al-Khalidi HR, Ansell J, Atar D, Avezum A, Bahit MC, Diaz R, Easton JD, Ezekowitz JA, Flaker G, Garcia D, Geraldes M, Gersh BJ, Golitsyn S, Goto S, Hermosillo AG, Hohnloser SH, Horowitz J, Mohan P, Jansky P, Lewis BS, Lopez-Sendon JL, Pais P, Parkhomenko A, Verheugt FW, Zhu J, Wallentin L, Apixaban versus warfarin in patients with atrial fibrillation. $N$ Engl J Med., 2011; 365(11): 981-992

25. Powers WJ, Rabinstein AA, Ackerson T, Adeoye OM, Bambakidis NC, Becker K, Biller J, Brown M, Demaerschalk BM, Hoh B, Jauch EC, Kidwell CS, Leslie-Mazwi TM, Ovbiagele B, Scott PA, Sheth KN, Southerland AM, Summers DV, Tirschwell DL; American Heart Association Stroke Council, Guidelines for the early management of patients with acute ischemic stroke: a guideline for healthcare professionals from the American Heart Association/American Stroke Association. Stroke, 2018; 49(3): e46-e110.
26. Gulseth MP, Michaud J, Nutescu EA, Rivaroxaban: an oral direct inhibitor of factor Xa. Am J HealthSyst Pharm., 2008; 65: 1520-1529.

27. Henkey G, Secondary stroke prevention. Lancet Neurol., 2014; 13(2): 178-194.

28. Hickey JV, The clinical practice of neurological and neurosurgical nursing. $6^{\text {th }}$ ed. Philadelphia: Lippincott, Williams and Wilkins; 2008.

29. www.activase.com.

30. Hull RD, Raskob GE, Hirsh J, Jay RM, Leclerc JR, Geerts WH, Rosenbloom D, Sackett DL, Anderson $\mathrm{C}$, Harrison L, Continuous intravenous heparin compared with intermittent subcutaneous heparin in the initial treatment of proximal-vein thrombosis. $N$ Engl J Med., 1986; 315(18): 1109-1114.

31. Kay R, Wong KS, Yu YL, Chan YW, Tsoi TH, Ahuja AT, Chan FL, Fong KY, Law CB, Wong A, Low-molecular-weight heparin for the treatment of acute ischemic stroke. $N$ Engl J Med., 1995; 333(24): 1588-1593.

32. Kim JT, Heo SH, Park MS, Chang J, Choi KH, Cho $\mathrm{KH}$, Use of antithrombotics after hemorrhagic transformation in acute ischemic stroke. PLoS One, 2014; 9(2): 1-7.

33. Larsson SC, King A, Madigan J, Levi C, Norris JW, Markus HS, Prognosis of carotid dissecting aneurysms: results from CADISS and a systematic review. Neurology, 2017; 88: 646-652.

34. Țica OA, Țica A, Antal L, Hatos A, Popescu MI, Stoian AP, Bratu OG, Găman MA, Pițuru SM, Diaconu CC, Modern oral anticoagulant treatment in patients with atrial fibrillation and heart failure: Insights from the clinical practice. Farmacia, 2018; 66(6): 972-976.

35. Paveliu MS, Lorenzovici L, Tudose C, Oral anticoagulant treatment with antivitamin $\mathrm{K}$ in Romania. A cost-effectiveness analysis of using inr home testing devices. Farmacia, 2018; 66(2): 358364.

36. Miyares MA, Davis K, Newer anticoagulants: a review of laboratory monitoring options and reversal agents in the hemorrhagic patient. Am J Health-Syst Pharm., 2012; 69: 1473-1384.

37. Shahpouri MM, Mousavi S, Khorvash F, Mousavi SM, Hoseini T, Anticoagulant therapy for ischemic stroke: A review of literature. J Res Med Sci., 2012; 17(4): 396-401.

38. Alquwaizani M, Buckley M, Adams C, Fanikos J, Anticoagulants: A review of the pharmacology, dosing, and complications. Curr Emerg Hosp Med Rep., 2013; 1(2): 83-97.

39. Mohan KM, Wolfe CG, Rudd AG, Heuschmann PU, Kolominsky-Rabas PL, Grieve AP, Risk of cumulative risk of stroke recurrence: a systemic review and meta-analysis. Stroke, 2011; 42: 14891494.

40. Mokin M, Kass-Hout T, Kass-Hout O, Radovic V, Siddiqui AH, Levy EI, Snyder KV, Intravenous heparin for the treatment of intraluminal thrombus in patients with acute ischemic stroke: a case series. $J$ Neurointerv Surg., 2013; 5:144-150.

41. Glenview IL, American Association of Neuroscience Nurses, 2010, ISBN 978-0-983132-40-0, 5th edition. 
FARMACIA, 2019, Vol. 67, 1

42. Paciaroni M, Agnelli G, Falocci N, Caso V, Becattini C, Marcheselli S, Rueckert C, Pezzini A, Poli L, Padovani A, Csiba L, Szabó L, Sohn SI, Tassinari T, Abdul-Rahim AH, Michel P, Cordier M, Vanacker P, Remillard S, Alberti A, Venti M, Scoditti U, Denti L, Orlandi G, Chiti A, Gialdini G, Bovi P, Carletti M, Rigatelli A, Putaala J, Tatlisumak T, Masotti L, Lorenzini G, Tassi R, Guideri F, Martini G, Tsivgoulis G, Vadikolias K, Liantinioti C, Corea F, Del Sette M, Ageno W, De Lodovici ML, Bono G, Baldi A, D'Anna S, Sacco S, Carolei A, Tiseo C, Acciarresi M, D'Amore C, Imberti D, Zabzuni D, Doronin B, Volodina V, Consoli D, Galati F, Pieroni A, Toni D, Monaco S, Baronello MM, Barlinn K, Pallesen LP, Kepplinger J, Bodechtel U, Gerber J, Deleu D, Melikyan G, Ibrahim F, Akhtar N, Mosconi MG, Bubba V, Silvestri I, Lees KR, Early recurrence and cerebral bleeding in patients with acute ischemic stroke and atrial fibrillation: effect of anticoagulation and its timing: the RAF study. Stroke, 2015; 46: 2175-2182.

43. Patel MR, Mahaffey KW, Garg J, Pan G, Singer DE, Hacke W, Breithardt G, Halperin JL, Hankey GJ, Piccini JP, Becker RC, Nessel CC, Paolini JF, Berkowitz SD, Fox KA, Califf RM; ROCKET AF Investigators, Rivaroxaban versus warfarin in nonvalvular atrial fibrillation. $N$ Engl J Med., 2011; 365(10): 883-891.

44. ROCKET AF Study Investigators, Rivaroxaban once daily, oral, direct factor Xa inhibition compared with vitamin $\mathrm{K}$ antagonism for prevention of stroke and Embolism Trial in Atrial Fibrillation: rationale and design of the ROCKET AF study. Am Heart J., 2010; 159(3):340-347.

45. Rybak I, Ehle M, Buckley L, Fanikos J, Efficacy and safety of novel anticoagulants compared with established agents. Ther Adv Hematol., 2011; 2: 175195.

46. Schulman S, Beth RJ, Kearon C, Levine MN, Hemorrhagic complications of anticoagulant and thrombolytic treatment: American College of Chest Physicians Evidence-Based Clinical Practice Guidelines $\left(8^{\text {th }}\right.$ Edition). Chest, 2008; 133: 257S298S.

47. Selleng K, Warkentin TE, Greinacher A, Heparininduced thrombocytopenia in intensive care patients. Crit Care Med., 2007; 35: 1165-1176.

48. Spinler BE, Baetz SA, Dabigatran etexilate: an oral direct thrombin inhibitor for prophylaxis and treatment of thromboembolic diseases. Pharmacotherapy, 2008; 28: 1354-1373.

49. Connolly JS, Dabigatran versus warfarin in patients with atrial fibrillation. $N$ Engl $J$ Med., 2009; 361: 1139-1151.
50. The International Warfarin Pharmacogenetics Consortium. Estimation of the warfarin dose with clinical and pharmacogenetic data. $N$ Engl J Med., 2009; 360: 753-364.

51. The Publications Committee for the Trial of ORG 10172 in Acute Stroke Treatment (TOAST) Investigators, Low molecular weight heparinoid, ORG 10172 (danaparoid), and outcome after acute ischemic stroke: A randomized controlled trial. JAMA, 1998; 279: 1265-1272

52. Larsen TB, Skjoth F, Nielsen PB, Kjældgaard JN, Lip GYH, Comparative effectiveness and safety of non-vitamin $\mathrm{K}$ antagonist oral anticoagulants and warfarin in patients with atrial fibrillation: propensity weighted nationwide cohort study. BMJ, 2016; 353: 1-9.

53. Turpie A, Lassen MR, Davidson BL, Bauer KA, Gent M, Kwong LM, Cushner FD, Lotke PA, Berkowitz SD, Bandel TJ, Benson A, Misselwitz F, Fisher WD, RECORD4 Investigators, Rivaroxaban versus enoxaparin for thromboprophylaxis after total knee arthroplasty (RECORD4): a randomised trial. Lancet, 2009; 373: 1673-1680.

54. Feigin VL., Norrving B, Mensah GA, Global burden of stroke. Circ Res., 2017; 120(3): 439-448.

55. Vellimana AK, Kadkhodayan Y, Rich KM, Cross DT $3^{\text {rd }}$, Moran CJ, Zazulia AR, Lee JM, Chicoine MR, Dacey RG Jr, Derdeyn CP, Zipfel GJ. Symptomatic patients with intraluminal carotid artery thrombus: outcome with a strategy of initial anticoagulation. J Neurosurg., 2013;118: 34-41.

56. Weitz DS, Weitz JI, Update on heparin: What do we need to know? J Thromb Thrombolysis, 2010; 29: 199-207.

57. Whiteley WN, Adams HP Jr, Bath PM, Berge E, Sandset PM, Dennis M, Murray GD, Wong KS, Sandercock PA, Targeted use of heparin, heparinoids, or low-molecular-weight heparin to improve outcome after acute ischaemic stroke: an individual patient data meta-analysis of randomised controlled trials. Lancet Neurol., 2013; 12: 539-545.

58. Wong KS, Chen C, Ng PW, Tsoi TH, Li HL, Fong WC, Yeung J, Wong CK, Yip KK, Gao H, Wong HB, FISS-tris Study Investigators, Low-molecularweight heparin compared with aspirin for the treatment of acute ischaemic stroke in Asian patients with large artery occlusive disease: A randomised study. Lancet Neurol., 2007; 6(5): 407-413.

59. www.escardio.org.

60. Yi X, Lin J, Wang C, Zhang B, Chi W, Lowmolecular-weight heparin is more effective than aspirin in preventing early neurologic deterioration and improving six-month outcome. $J$ Stroke Cerebrovasc Dis., 2014; 23(6): 1537-1544. 